\title{
Especial
}

\section{AOS NOSSOS INIMIGOS. REFLEXÕES SOBRE O PÚBLICO}

TO OUR ENEMIES. REFLECTIONS ON AUDIENCE

A NUESTROS ENEMIGOS. REFLEXIONES SOBRE EL PÚBLICO

Óscar Cornago

\section{Óscar Cornago}

Pesquisador do Centro de Ciências Humanas e Sociais do Consejo Superior de Investigaciones Científicas (CSIC), em Madri, escritor, estudou e documentou o trabalho de artistas da cena contemporânea na Espanha e América Latina em volumes, tais como Políticas de la palabra, Éticas del cuerpo e Acercamientos a lo real. 


\section{Resumo}

Este trabalho tem o objetivo de estudar a construção do público, entendido como os interlocutores em ação, a partir de duas histórias diferentes. A primeira consiste em uma conversação improvisada da dupla de performers Los Torreznos, em La caverna (2012), que tinha o público como seu objeto de observação; e a outra é extraída da análise que o Comité Invisible fez sobre o movimento de ocupação das praças, ocorrido em diferentes cidades do mundo desde 2008. O objetivo é confrontar duas abordagens diferentes do público - cênica e estética, por um lado, e social e política, por outro - e traçar um caminho de ida e volta entre a cena e a rua, considerando ambos os espaços como dispositivos de ação e de representação que buscam operar de outras maneiras ante a ordem política e econômica, reforçada desde a década de 1990.

Palavras-chave: Público, Performance, Revolução social, Estética, Dispositivo.

\section{Abstract}

The aim of this article is to study the constitution of the audience, understood as an interlocutor in action, based on two different stories. The first one is an improvised dialogue by the artistic duet Los Torreznos, in La caverna (2012), in which the audience was their object of observation; the other one is extracted from the analysis made by the Comité Invisible about the occupation movement in squares all over the world since 2008. The objective is to confront two different approaches of audience - scenic and esthetic, on one hand, and social and political, on the other - and trace an inward and outward journey between scene and street, considering both spaces as mechanisms of action and representation, operating differently before the political and economic order, reinforced since 1990.

Keywords: Audience, Performance, Social revolution, Esthetic, Device.

\section{Resumen}

El objetivo de este artículo es estudiar la construcción del público, entendido como los interlocutores de una acción, a partir de dos relatos distintos. Uno está formado por la conversación improvisada del dúo de performers Los Torreznos en su obra La caverna (2012), que tenía al público como objeto de su mirada; y el otro está extraído del análisis de Comité Invisible del movimiento de ocupación de las plazas desarrollado en distintas ciudades del mundo desde el 2008. La finalidad es confrontar dos acercamientos distintos al público -Escénico y estético, por un lado, y social y político, por otro-, y trazar un camino de ida y vuelta entre la escena y la calle, considerando ambos espacios como dispositivos de actuación y representación que están buscando otras formas de operar frente al orden económico y político consolidado desde los años noventa. Palabras clave: Público, Performance, Revolución social, Estética, Dispositivo. 
"Escrever é um ato de vaidade, se não é para o amigo."

Presente no livro A nuestros amigos, escrito por um autor ou autores que permanecem sob o anonimato do Comité Invisible, essa afirmação poderia ser levada, talvez com razão, para a cena. Estar em cena pode ser entendido também como um ato de vaidade se não é feito para um amigo. O público, que em sentido figurado pode ser considerado como um tipo de inimigo que deve ser conquistado, pode igualmente ser aquele amigo que ainda não é conhecido, conforme o Comité Invisible costuma dizer referindo-se aos seus potenciais leitores. Chamá-los de "amigos" é apenas parte de uma retórica, uma forma de se tornar público e de se relacionar com o público. Entre um ponto e outro, entre o antagonismo radical e o desejo de proximidade, colaboração ou trocas com os interlocutores de um projeto, são realizadas inúmeras opções que expressam diferentes formas de estabelecer a relação entre palco e plateia, ou em sentido mais amplo entre aqueles que são reconhecidos na rua, voluntariamente ou não, e aqueles que assistem do anonimato de sua condição como cidadãos comuns; diferentes formas, em suma, para compreender o fenômeno social no momento em que está ocorrendo. Esta abordagem levanta uma série de questões que ocupam um lugar importante no atual debate tanto em nível político como artístico: Quem assiste e quem atua? Como abordar novas formas de ação com os outros? Como reinventar os espaços comuns ? $^{1} \mathrm{Ou}$, dando uma formulação mais específica:

No século XVII, quando Tristão e Isolda se encontram pela noite e conversam, trata-se de um "parlamento"; quando algumas pessoas, entregues ao destino da rua e das circunstâncias, agitadas, começam a discutir, trata-se de uma "assembleia". Isso é o necessário para opor a "soberania" das assembleias gerais aos falatórios dos parlamentos: a redescoberta da carga afetiva ligada à palavra, à verdadeira palavra. $\mathrm{O}$ oposto da democracia não é a ditadura, é a verdade. É precisamente porque são esses os momentos da verdade, em que o poder aparece sem disfarce, que as revoltas nunca são democráticas. (COMITÉ INVISIBLE, 2015, tradução nossa, p. 68)

1. Este trabalho é parte do projeto "Las prácticas escénicas como forma social del conocimiento. Una aproximación crítica a la idea de participación", financiado pelo Ministerio de Economía y Competitividad (HAR2014-57383-P). 


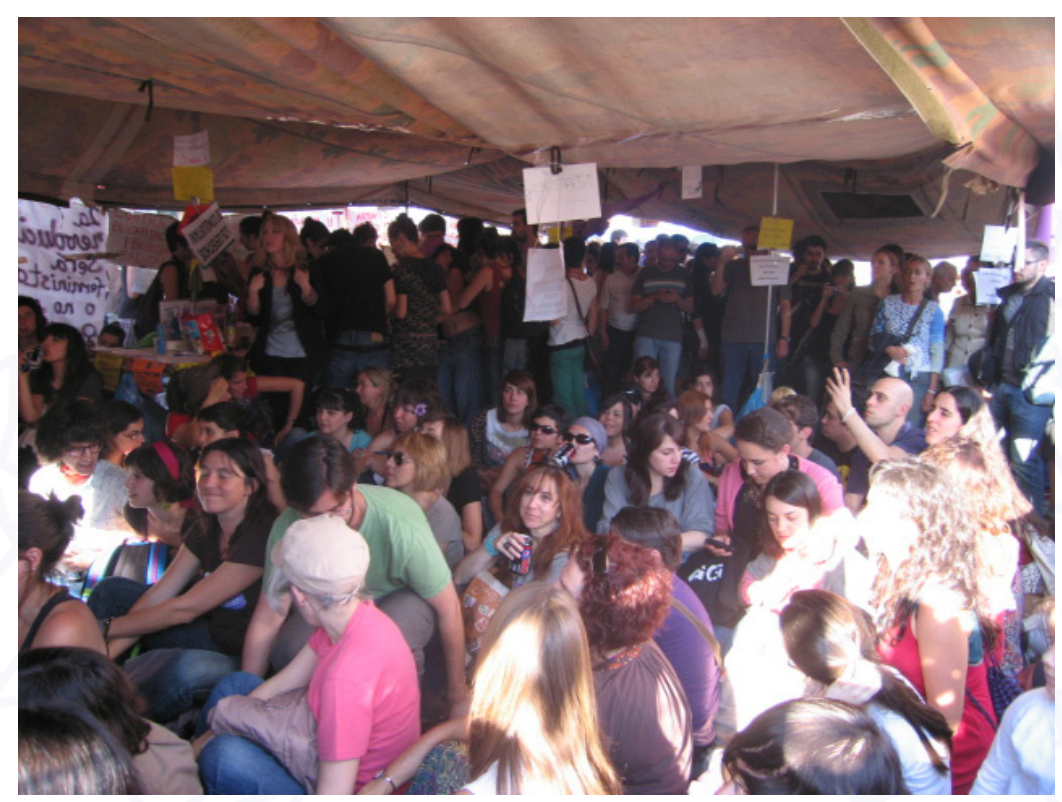

Foto: Belém Cueto

As seguintes reflexões foram feitas em diálogo com dois textos, que não são apenas textos, porque se referem diretamente a ações que serviram de base para esses textos. No primeiro caso, trata-se de uma obra de Los Torreznos, La caverna, realizada em diversos espaços, e o outro - do qual extraí a citação anterior - resulta de uma série de manifestações ocorridas desde 2008 em diferentes cidades do mundo e que, entre outras denominações, ficaram conhecidas como o Movimento das praças. Qualquer texto, assim como toda palavra, deriva de uma ação. A cultura ocidental é frequentemente criticada por ser excessivamente intelectual, por valorizar mais a representação e os discursos do que o evento a que se referem. Como resposta, há tempos a ação se tornou um instrumento-chave paradoxalmente também transformado em um discurso, não menos importante, de transformação. A ação abre a possibilidade de propor outro tipo de relações com as representações, começando com as representações de nós mesmos. Os textos são suportes fundamentais para esse tecido intelectual, e são questionados pelas mesmas ações que os sustentam, ou melhor, pela sua ausência: em vez de fazer, escrever/dizer. Certamente, dizer/escrever é uma ação e, portanto, inevitavelmente também é um palco. Dependendo dos casos, essas ações podem tornar-se mais visíveis ou, ao contrário, passar despercebidas para dar maior reputação ao texto/palco como uma entidade autônoma, contribuindo também para sua projeção no tempo, ou seja, para lhe conferir maior poder 
enquanto texto ante seus potenciais inimigos, leitores ou a ausência deles. Maior reputação pode atrair mais público, mas também dificulta transformá-lo em algo que não seja uma projeção da própria reputação.

Por essa razão, talvez, um dos materiais que vou expor neste texto tem uma reputação muito restrita, uma vez que é resultado de uma transcrição feita por mim de parte de uma improvisação cênica. Essa transcrição também pode ser qualificada como uma deturpação, já que é resultado ilegítimo de uma ação cujo sentido é precisamente evitar a possibilidade de ser fixado em texto. Isso a transforma em um texto dramático, que por sua vez poderia servir de base para uma futura montagem com alguns atores, exatamente o modelo artístico contra o qual se propõe esse tipo de trabalho, descendente da corrente de performance que se ativa novamente na Espanha a partir do início da década de 1990.

La caverna foi realizada por Rafael Lamata e Jaime Vallaure, que formaram a dupla Los Torreznos no início dos anos 2000. O ponto de partida é uma ideia lançada pelo artista Isidoro Valcárcel Medina, um renomado expoente do movimento da arte conceitual que teve muita influência no desenvolvimento da performance. Inspirada no mito homônimo de Platão, a proposta foi adaptada pela dupla da seguinte maneira. Durante 30 minutos, um deles fica sentado de costas para o público e o outro fica na sua frente, em pé, portanto também de frente para o público. Entre eles se desenvolve um diálogo que surge a partir dessa situação, o que um pode ver e sentir ao olhar para o público, e o outro não. Após esse tempo, a atuação é interrompida por um blecaute, as posições são trocadas e o jogo começa novamente por mais 30 minutos. Como em todos os trabalhos desenvolvidos pela dupla, o que se diz em cena, embora existam orientações ou algum roteiro, é resultado da improvisação. Seguindo o espírito da performance, o que acontece lá é, de algum modo, resultado desse momento e dessa situação, e não um trabalho pronto que se repete da mesma forma a cada vez que é realizado. Embora idealmente qualquer evento cênico responda a essas premissas, daí a necessidade de um formato cênico em vez de um formato apenas visual ou textual, os níveis de abertura de cada variam de acordo com as convenções, gêneros e modos de trabalho. Não é de se estranhar, portanto, a pergunta que dá início à conversa: "Como estamos aqui e agora?". 
- Você está bem?

- Finalmente, tirando alguns incômodos... mas a questão é quanto você se importa.

- Com os incômodos?

- Sim, sim, com os incômodos. Mas, enfim, basicamente estou bem.

- Então... você está bem?

- Sim, sim, estou bem. Já te falei.

- Mas eu estou achando você um pouco inquieto.

- Bom, é que não é uma situação tão fácil, é como se fosse normal, mas não é normal.

- Não é normal?

- Não, não é.

- Por que não é normal?

- Não é normal porque... acontecem coisas aqui. Não sei se você está percebendo.

- $\quad$ O que eu percebo é que você não fixa seu olhar. Você está olhando para um lado e para o outro.

- Bom, me distraio, sim. É que eu vejo coisas que me distraem. Já te falei que essa situação não é normal. Mas, vamos lá, se você quiser, eu olho nos seus olhos.

- Bom, eu não sei, é que me chama a atenção.

- Mas o que mais acontece? O que se faz é para passar o tempo. Olha, agora olho nos seus olhos.

- Você está bem?

- Mais uma vez! Sim, cara, sim, com certeza.

- Eu também.

- Bom, fico feliz. É isso, estar bem, porque se a gente estivesse mal, iríamos para outro lugar.

- $\quad$ Sim e não. Você poderia estar aqui se sentindo mal.

- $\quad$ Sim, mas então não estaria assim. Estaria mal e essas coisas são percebidas. 
- Você compreende quando está bem e quando está mal, de verdade?

- Olha... sei lá. Depende do momento. Há momentos em que as pessoas estão conscientes de que estão bem, e outros em que não sabem, e não precisam saber, simplesmente devem estar, está e é isso. Vamos lá, eu digo. Você não sabe se você está bem o tempo todo, simplesmente está.

O outro interlocutor deste ensaio é o livro já mencionado, $A$ nuestros amigos, que em sua primeira frase, escrita em maiúsculas, já deixa claro o ponto de partida: "AS REVOLTAS, FINALMENTE, CHEGARAM". O início do primeiro capítulo marca o lugar proposto pelo livro, que não é diferente do "como estamos?" que abriu a conversa de Los Torreznos: "Nós, revolucionários, somos os grandes cornos da história moderna", ao que é complementado se resta alguma dúvida sobre as responsabilidades: "E a gente sempre é, de uma maneira ou de outra, cúmplice de quem colocou os chifres" (COMITÉ INVISIBLE, p. 21, tradução nossa). Então, a resposta parece óbvia: estamos ferrados.

O Comité Invisible tem como base algumas situações de protestos que não só não tiveram o efeito político esperado, mas em alguns casos desencadearam uma reação conservadora, o que nos dá a impressão de que os autores parecem ter participado ativamente desses eventos, pois eles não se apresentam apenas como espectadores privilegiados, mas também atores. Pelo modo como surgiram, compartilham alguns traços que chamaram a atenção também do meio artístico. A análise que apresentam tem um panorama cênico, à medida que se detém sobre de que forma, material e física, tudo aconteceu. Isso contribui, como o que fiz ao transcrever o texto de Los Torreznos, para estabelecer algo que se originou justamente de uma reação ao que estava estabelecido - representado - como formas políticas assumidas por todos: a evidência da democracia. Embora tanto o discurso do Comité Invisible quanto esse exercício de transcrição resistam a esse efeito de fixar o que foi um evento vivo, esse é o preço que se paga para recuperar alguma coisa para a história, a consequente possibilidade de capitalizá-lo de uma forma ou de outra. Isso é justamente o que aconteceu, talvez inevitavelmente, com o aproveitamento do embalo desses movimentos por alguns partidos políticos. No 
entanto, quando esses protestos estavam ocorrendo o importante não era sua projeção para o futuro, mas sua potência própria, resultado da forma como tudo estava acontecendo. Isso impregnou os movimentos de uma qualidade cênica na qual o artístico e o social se fundiram. Questões tão básicas, como a forma de estar ali, a atitude das pessoas, as relações que se foram tecendo, o processo de auto-organização tomado como uma tarefa coletiva, o cuidado de uns com os outros e a forma como, em última análise, tornar público tudo isso, não apenas como uma representação, mas como algo inerente àquilo que estava ocorrendo, foram os elementos fundamentais que deram forma a esses encontros, transformando-os em um fenômeno singular muito além do conteúdo das frases, de caráter, por outro lado, bastante geral diante da natureza específica da situação que se estava vivendo.

Esse mundo feliz também teve seu outro lado, ao que o Comité Invisible se refere para tentar explicar por que, para a execução de uma determinada ação votada por uma maioria, alguns dias depois, nem mesmo a décima parte daqueles que tinham votado se apresentaram, ou por que demorar muito tempo para gerar um documento cuja validade seria logo limitada. Provavelmente, era mais importante o caminho e a maneira como percorrê-lo do que o objetivo. A intensidade do presente parecia ir contra sua projeção de futuro. O valor desses cenários se resumia no simples fato de estar acontecendo contra todas as probabilidades, embora não se tivesse certeza para que isso poderia servir. Simplesmente já estava servindo, pelo menos para todos aqueles que estavam ligados de alguma forma a esse contexto, seja por meio de participação direta, ou simplesmente pela sensação de que aquilo estava ocorrendo. Esses movimentos estimularam um conjunto de afetos, energias, desejos e emoções com uma poderosa capacidade de se propagar. Antes mesmo de se questionar seu intuito, já estavam tendo um efeito. Abria-se uma brecha no horizonte do improvável.

- Sim, eu gosto do que você está dizendo... mas o contexto. Me fale, por favor, sobre o contexto.

- Bom, o contexto... é um contexto desproporcional. É desproporcional. Há muito em um lado e muito pouco no outro. Isso determina a situação global.

Sim, está certo, o desequilíbrio. Há um desequilíbrio. 
- Mas dentro do desequilíbrio existem duas fases que são... Mas, bom, você sabe que isso... vamos lá, pode acontecer alguma coisa.

- Cara, não me assuste.

- N Não, cara, não. O que quero dizer é que coisas podem acontecer.

- Onde?

- Aqui, cara, aqui.

- No contexto?

- Sim, no contexto, sim, aqui.

- Mas que tipo de coisas?

- Bom, de repente... (Ouve-se algo da parte do público, como, risadas, sussurros, alguém se movendo...) Olha aí!

- N Não, eu não vejo nada. Vejo você.

- Sim, claro, por isso, porque não acontecem, mas de repente, há algumas rupturas... vê?

- Tempestades, há tempestades.

- De repente, há algumas rupturas. Não notou nada de estranho antes?

Qualquer cena contrai uma dívida com o lugar que a dá origem, mas também com aqueles aos quais é dirigida, com esses potenciais amigos ou inimigos que é o público. Mesmo que por rejeição ou indiferença, uma cena está destinada para alguém, projetada para os outros. Tem um destino público. É uma promessa de reunião com algo externo; a possibilidade de que ocorra, sem previsão, alguma coisa que atravesse a situação presente. À medida que está mais aberta, menos elaborada, é mais fácil detectar traços do contexto no qual acontece, sentir as fissuras do momento em que é feita, como é o caso do texto da dupla, cheio de repetições, dúvidas e rodeios. E, ao contrário, à medida que está mais fechada, dependerá menos do público. O texto ganha autonomia ao apagar as marcas de sua escrita; tornando-se menos restrito, pode aspirar a um público maior. A abertura operacional torna o trabalho mais dependente dos outros. No entanto, isso o faz perder autoridade - teórica - enquanto ganha poder, prática. A cena mantém uma relação com o contexto em que é produzida. Precisa dele, mas ao mesmo 
tempo isso pode acabar confundindo-a com a massa indiferenciada que o circunda.

Os dois interlocutores deste trabalho se situam em campos claramente distintos. É suficiente olhar as fotos que acompanham este texto, em que aparecem, por exemplo, frequentadores de vários eventos e manifestações públicas ${ }^{2}$, para verificar a distância entre um meio e outro, e entender também, apreciando a intensidade expressada nesses recortes, por que mais de um artista descobriu no Movimento das praças uma inspiração e um estímulo para seu trabalho. O objetivo deste artigo é estabelecer um diálogo entre dois espaços heterogêneos que, no entanto, não deixam de ter algo em comum. $\mathrm{O}$ ato de repensar o público com uma proposta de teatro em resposta aos eventos que ocorrem no espaço público nos últimos anos e, por outro lado, repensar os movimentos sociais como espaços teatrais. Se a rua pode ser considerada como o laboratório cênico por excelência, toda cena artística também pode ser vista como um laboratório social em miniatura. No caso do livro já citado, a construção de uma noção de público se dá de duas formas: como público/atores desses movimentos e como leitores do livro.

A busca por novas formas de se relacionar com o mundo e, portanto, com o público, e por meio dele com nós mesmos, nos obriga a olhar para o que acontece na rua como uma possibilidade cênica. Da mesma maneira que, por outro lado, toda cena tem algo de laboratório social. Dito isso, seria necessário forçar muito a análise para encontrar em La caverna alguma relação direta com o movimento de ocupação das praças. Essa não é minha intenção, mas também não é uma coincidência que este trabalho foi feito um ano após a ocupação da Puerta del Sol em Madri em 2011, que logo depois ficou conhecida como o "15-M". No mesmo ano de La caverna, ou seja, em 2012, Los Torreznos apresentaram mais dois trabalhos em que se dirigiam ao público de maneira mais direta, Ya llegan los artistas e, sobretudo, Las posiciones, em que os espectadores protagonizaram a obra de forma ainda mais evidente. A ponte que liga uma instância e outra, a cena artística e a rua, são

2. Embora as imagens da rua são do movimento 15-M de Madri, foram postas aqui como exemplo de cenografias humanas. Poderiam ser de outro movimento que ocorreu durante esses anos. Não foi considerado necessário detalhar a procedência das outras imagens do público, que não correspondem, do mesmo modo, ao trabalho de Los Torreznos, e que poderiam corresponder a diferentes eventos cênicos. 
as pessoas, o componente fundamental que alimenta tanto uma obra teatral como um movimento social. Embora o público possa ser de diferentes áreas, dependendo do tipo de trabalho ou movimento, ambos partilham essa indefinição que alude à noção de pessoas como material humano sobre o qual se trabalha.

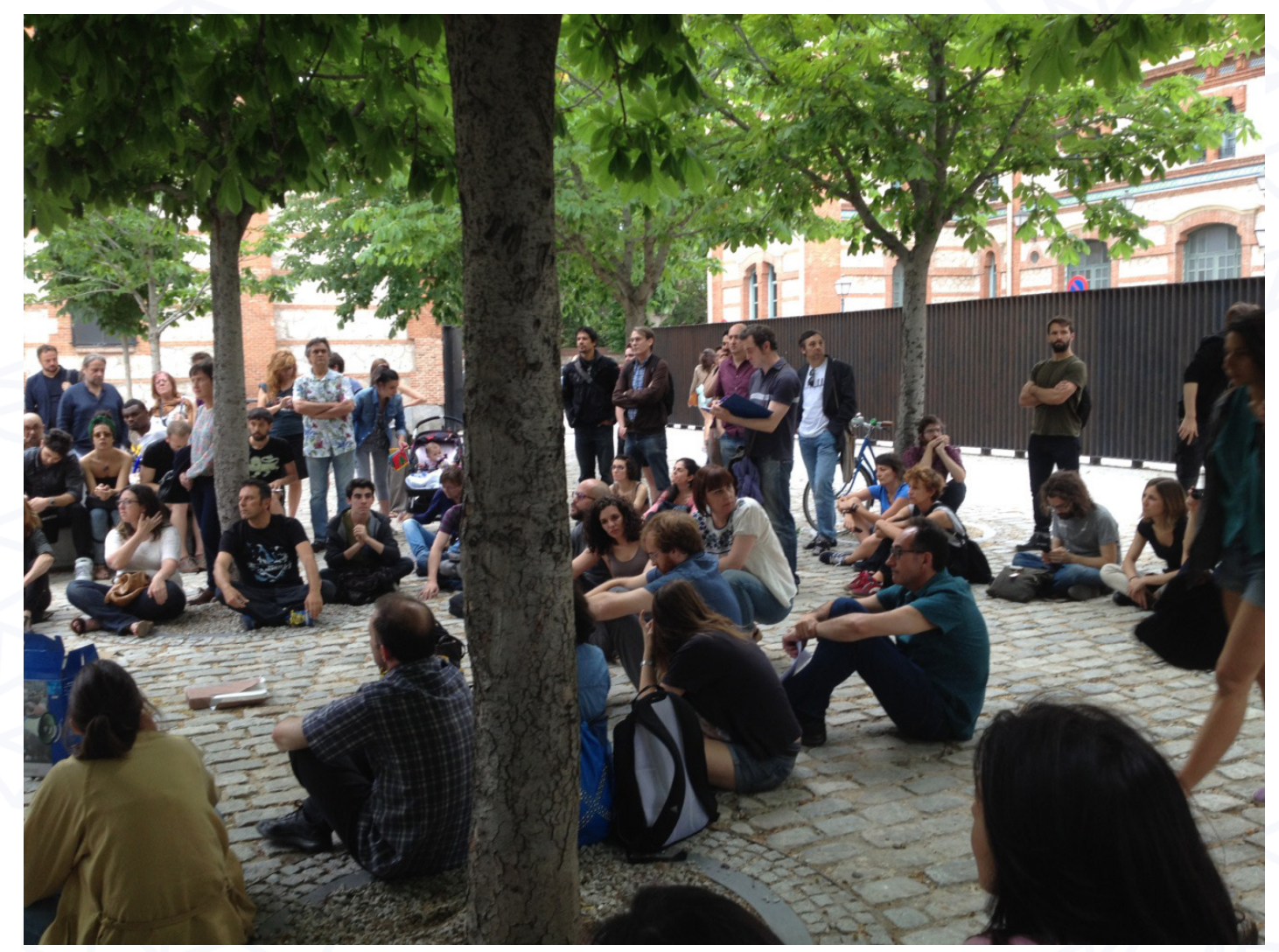

Foto: Belém Cueto

Na rua e em cena, o horizonte são os outros, aqueles que podem se fazer visíveis, os que ainda não tomaram a palavra, mas poderiam fazê-lo. $O$ indiferenciado desses grupos, identificado como público, povo, pessoas, esses $99 \%$, transformado em slogan desses movimentos, foi recuperado como um elemento importante. Antes de estudantes, trabalhadores ou ativistas, são apresentados simplesmente como pessoas. Ao contrário de outros tempos em que se buscava a identificação de grupos com características ideológicas, culturais ou artísticas específicas que lhes dessem mais capacidade de projeção:

A revolta é, em primeiro lugar, a obra daqueles que não são nada, dos que vagueiam em cafés, nas ruas, na vida, na faculdade, na internet [...]. Os que se revoltam não têm ninguém para colocar no trono como 
um substituto, à exceção, talvez, de um ponto de interrogação. Eles não são nem os excluídos, ou a classe trabalhadora, ou a pequena burguesia, nem as multidões que se revoltam. Ninguém com homogeneidade suficiente para admitir um representante. (Ibid., p. 44-45, tradução nossa)

Isso se poderia dizer do público de um evento cultural, ainda mais se for um trabalho de caráter experimental, longe de ser heterogêneo, ao contrário, que tende a ser bastante uniforme. No entanto, o que estamos propondo opera em dois níveis diversos: por um lado, a realidade social de que faz parte e, por outro, o tratamento que se faz dela, isto é, dirigir-se ao público como representante de uma determinada classe social ou profissional, como artistas, gestores, estudantes, grupos pertencentes a uma determinada esquerda cultural ou pessoas interessadas pelo mundo da cultura em geral, ou se dirigir a ele apelando para um senso comum que idealmente poderia servir para qualquer um que tenha algo desse "não ser nada", ao que se refere o Comité Invisible, que finalmente somos todos, ou quase todos os que têm algo "daqueles que vagueiam em cafés, nas ruas, na vida, na faculdade, na internet". No entanto, dependendo do peso das identidades e dos contextos, esse fundo de indeterminação pode ser mais ou menos acessível ou protegido. A falta de credibilidade das articulações construídas com base em rótulos facilmente reconhecíveis conduziu à recuperação desse espaço comum que ultrapassa as funções determinadas pela atividade profissional ou cultural. A recuperação nas últimas décadas da figura do amador como alguém que se relaciona com uma atividade por paixão também é explicada por essa situação. A impossibilidade de articular uma força social renovadora a partir dessas identidades obriga a recorrer cotidianamente a matrizes de socialização mais básicas, semelhante a essa mesma paixão com que algo é feito.

\footnotetext{
- Mas o contexto... está bem? Quero dizer, você está bem, e o contexto também?

- Bom, o contexto está bem disposto, muito bem disposto. Está em ordem, classificado. Está misto. É um contexto positivo. Sim, agora é. É um contexto aberto. Com vontades. É um contexto...
} 
- Cara, essas coisas a gente percebe.

- No ar?

- Sim, no ar. Há um clima geral, que está aí, que se estabelece. Você não vê algo aí atrás?

- Por aqui?

- S Sim, por aí. Você não vê algo incomum?

- Não.

- Ah, é que você começa a fazer movimentos estranhos.

- É que estou tentando perceber... mas, eu não sei. Não saberia distinguir se um contexto é bom ou não.

- Mas é.

- Você está calmo?

— S Sim, bem... enfim, também não é uma situação fácil.

- Mas eu posso ficar calmo, ou tenho que estar inquieto?

- Cara, eu não poderia estar totalmente relaxado. As coisas podem acontecer a qualquer momento.

Diante do impasse de organizar a cena para que se sustente com garantias de se chegar a certo ponto ou, pelo contrário, correr o risco de dissolvê-la devido à falta de uma autoridade que a ordene, o Comité Invisible se coloca no plano operacional do sistema. "Querem nos forçar a governar. Não cairemos nessa provocação" é o título do que pode ser considerado o segundo capítulo, que, como os demais títulos no livro, foram retirados de pichações de rua dos diferentes espaços das manifestações. As implicações dessa negação são óbvias: sair da política para poder continuar sendo políticos, que traduzido para o mundo da arte seria "sair da arte para permanecer artístico". Essa retórica está longe de ser nova, é um clássico, no entanto, foi formulada de maneira diversa, porque as formas de fazer arte ou política e, portanto, de tentar sair desses campos, não deixaram de mudar. Se hoje o meio artístico se propõe como um espaço de relações, a outra face desse modelo é a maneira de organizar essas relações. Renunciar a uma forma convencional de governo supõe quebrar as regras do jogo, que sustentam um cenário basea- 
do em alguma autoridade, na do líder, do intelectual, do artista, do ator ou do político. Essa massa aparentemente sem forma, que é o público, perde o caráter abstrato que recebe por ser uma função do cenário no qual se situa, mas para o qual nunca deixa de ser estranha. O público abandona seu anonimato, não individualmente, mas como grupo, e passa a ser a única possibilidade para a cena, já não apenas teórica - tantas vezes invocada pela afirmação carregada de retórica de que o público é o mais importante da cena -, mas agora também física e sensível. Se é possível continuar considerando a possibilidade de ação, ela já não deve ser direcionada somente a um grupo do qual se quer provocar reação, mas tem que começar a partir dele. Isso supõe expor ao público outro tipo de relação/função, que o retire de sua identidade genérica de espectador passivo, o que limita a sua variedade de respostas ao conhecido "gostei/não gostei".

O exemplo paradigmático da falta de definição social em que são postos modelos, tais como pessoas ou a sociedade em geral, pode ser novamente o público como uma forma coletiva característica de uma sociedade de consumidores. Quem pode se sentir identificado com algum tipo de público, quem procura através de sua condição de público um jeito de se identificar socialmente, e, no entanto, quem pode dizer que não é parte do público quase constantemente? Essa condição tão avassaladora quanto abstrata, aberta a todos e voluntariamente apoiada por ninguém, dissolveu outras formas de socialização que não se sustentavam economicamente. Fazer parte de uma sociedade hoje, mais do que nunca, é determinado pela forma de consumir. Isso exige expor novamente o jogo cênico desde seus elementos básicos; repensar o social, o fato do encontro, desde a base, que é o povo, o público ou os outros, aquilo que somos quando deixamos de lado o disfarce que nos faz artistas ou professores, gestores ou revolucionários. Esse é o sujeito comum proposto como um modelo de ator dos movimentos sociais e de cenários de criação.

\footnotetext{
- Eu não sei, então me diga o que está havendo.

- Existem..... não sei como dizer isso. São como... figuras.

- Existem figuras e você está calmo?
} 
- É que se a gente fica nervoso... você sabe que as figuras reagem imediatamente. As figuras são sensíveis, ficam nervosas também... não sei como te falar. Se esfarinha.

- Se esfarinha? O que é isso?

- Sim, o contexto, me refiro ao contexto. O contexto pode se esfarinhar, como que se decompor. Vai assim todo fluido e de repente há uma quebra.

- Mas onde você o vê?

- Bom... pode acontecer. Se as figuras percebem que você está nervoso, começam a...

- Mas você vê as figuras?

- Cara, claro que sim. No momento, elas não são vistas, mas espere um pouco.

- Mas o que elas fazem? As figuras estão onde têm que estar? Elas estão organizadas?

- Elas estão organizadas, dispostas, posicionadas. Elas estão esperando.

- Estão esperando.

- Bom, elas estão esperando que alguma coisa aconteça.

- E elas são armazenadas?

- Cara, armazenadas... digamos que seja isso. Não sei se é correto dizer que elas estão armazenadas. Elas estão em conjunto, eu diria, em vez de armazenadas.

- E qual é a diferença dos conceitos de armazenar e juntar?

- Porque se elas estivessem armazenadas, não estariam esperando por algo. Elas teriam chegado ao lugar diretamente. Seria seu lugar natural.

- E não é isso? É artificial?

- É uma situação artificial, totalmente artificial. Não é natural isso que está acontecendo, como você pode ouvir, há uma tendência a...

- E é falsa?

- Quem é falsa?

- A situação. 
- Falsa? Completamente. Enfim, é o que me parece.

- Talvez eu não estaria tão calmo se a situação fosse falsa.

- Bom, ah, mas alguém tem que resistir a isso.

Desde que a noção moderna de público foi formada na década de 1960, ligada à cultura de massa e à indústria do espetáculo, o público é um paradoxo que só pode se sustentar como uma figura abstrata. É o destino que enfrenta qualquer projeto cultural que, ao mesmo tempo que precisa dialogar com essa abstração, deve transformá-la, convencê-la ou doutriná-la. Transformado em um número, em um classificação ou uma estatística, o público, com suas acepções distintas - colaboradores, companheiros ou ministrantes -, é a peça-chave para aferir o sucesso de uma obra. No entanto, o público é o público, uma peça vazia sustentada por um grupo bastante uniforme e de comportamento previsível, dada a intensa aprendizagem a que é submetida. Nesse sentido, é um tópico e um lugar-comum, a que nem sempre interessa dar voz de verdade. A possibilidade de um movimento social começa hoje por esse trabalho corpo a corpo, capaz de fazer dessas figuras abstratas, objeto de todas as políticas, um fenômeno sensível, vivo e espontâneo.

- Mas o clima está...

- Eu diria que está bom.

- Dá para respirar?

- $\quad$ Sim, sim, flui bem. Você percebe que existe uma vontade...

- Não está contaminado?

- Não, não está contaminado. E há uma vontade positiva de querer entender.

- Mas é falsa.

- Sim, falsa, mas dentro dessa falsidade... dá no mesmo. Em uma situação falsa, você ainda pode tentar entender.

- Ah, é isso o que se chama de falsidade boa.

- Não, não...

- É o que você disse. 
- O que eu disse é que é uma situação artificial, e que esse contexto é um contexto em um ambiente bom.

- $\quad$ Não sei por que você diz que é bom.

- Bom, porque é. Não há mais nada que observar.

- Por que não há nenhuma doença?

- Para isso, me desculpe, mas eu não tenho parâmetros para medir, assim, precipitadamente, se há alguma doença. Não sei, pode ter.

- Em algum lugar?

- Sim, poderia ter alguma área doente, ou que estivesse prestes a adoecer. Há algum que está em outro espaço e tempo, pode ser que esteja doente e não saiba.

- Quem? As pessoas ou a área?

- Bom, você sabe que existem áreas que tendem a propagar doenças. Sempre. A doença gera um mal-estar ao seu redor. Propaga. Quando alguém começa, "Ai, estou tão mal!", gera preocupação. Bom, e eu estou resistindo, não ache que é uma situação fácil.

- E quando alguém resiste, pode se deixar levar.

- Pode ser dobrado, por exemplo. Pode quebrar, ou dar um golpe.

- Você pode quebrar?

- Sim, pode acontecer.

Se, por um lado, é necessário tornar a fazer do público um fenômeno terreno, sensível e singular, vinculado a a um espaço concreto, por outro lado, os sistemas de poder insistem em submetê-lo aos mecanismos econômicos enraizados em todos os níveis. Os dois capítulos seguintes do Comité Invisible dedicam-se à análise desses sistemas de poder, "O poder é logístico. Bloqueemos tudo!" e "Fuck off Google!" Essas novas formas de se organizar e de nos organizar afetam diretamente o mundo cênico: "A verdade é que o poder já não é mais essa realidade teatral a qual a modernidade nos acostumou" (p. 88, tradução nossa). Diferentemente da imagem clássica do theatrum mundi, é imposto outro modelo articulado como um mecanismo sem rosto humano e com uma capacidade de operação autônoma: "O poder contemporâneo é impessoal e de natureza arquitetônica, e não representati- 
vo e pessoal." (p. 89, tradução nossa). A única face do poder é a dos próprios usuários que o incorporaram para utilizá-lo. É o que se conhece como biopolítica ou, seu outro lado, biopoder, causadas por formas de governo que não estão limitadas a determinadas áreas, como a do trabalho ou da vida pública, mas que, à medida que tudo tende a se transformar em trabalho, atravessam todos os níveis da existência. "O poder agora é inerente à vida da mesma forma que esta é organizada tecnológica e comercialmente. Tem a aparência neutra dos equipamentos ou da página em branco do Google." (p. 90, tradução nossa). É o sistema em si, do qual somos parte como usuários, que exerce um poder que parece ser capaz de continuar a funcionar mesmo sem ter quem o governe. É por essa razão que os governos podem estar em exercício durante longos períodos ou até mesmo ter um poder vazio, e o sistema continua funcionando. O poder já não passa da cena para a plateia, em uma única direção, ou do ator para o espectador ou do empresário/político para o cliente. Embora localizados em posições diferentes, todos agora formam parte do sistema. Todos são atores e espectadores ao mesmo tempo. A questão é como se encarregar de um cenário do qual fazemos parte, mas que nos supera em todos os níveis. A obrigação de ter que assumir esse sistema entre todos colide com a indeterminação gramatical a que se refere esse "entre todos". Quem são "todos"? "Todos" não existe, não é uma realidade anterior com a qual se pode contar, mas uma abstração a que se deve dar corpo e cor, deve-se construí-la, senti-la, tocá-la e cheirá-la, para que se torne uma realidade social com um certo poder. A falta de dar um rosto aos responsáveis por essas redes de interesses e corporações sem corpo, o único corpo coletivo que permanece na cena é o público como representante dessa sociedade anônima que aprendeu a se movimentar, consumir, obedecer e resistir aos dispositivos tecnológicos, às comunicações on-line e organizações distantes impulsionadas por uma constante necessidade de atualização. Por isso as distintas paixões relacionadas com a manutenção do sistema, por um lado, que parafraseando Espinoza poderíamos qualificar de triste, e com tudo que o atravessa de um modo imprevisto, por outro: "Se as revoltas estão associadas primeiramente com a raiva e, depois, com a alegria, a democracia direta, em sua formatação, é antes de tudo uma questão para angustiados." (p. 67, tradução nossa). 
- E a cor e o cheiro? Me fale algo da cor.

- Ufa, para isso temos que semicerrar os olhos.

- Semicerrar os olhos?

- Sim, para ver a cor dominante precisa semicerrar os olhos, senão, você vê os tons, mas não as cores. Estou vendo o... bege.

\section{- Bege?}

- Sim, a cor bege. A cor bege. A cor bege.

- Essa é a dominante?

- Sim, é a mistura. Eu fiz uma soma cromática, e a dominante é a bege, que é um tom. $\mathrm{O}$ tom bege.

- Muito elegante!

- Sim, claro, não é uma situação normal.

- Claro, é uma situação de bege.

- Bom, você me perguntou da cor.

- Mas só bege?

- Cara, não vai ser o tempo todo bege. Senão, como se aguenta o tempo todo isso. Sempre tem um resquício. Deve ter um pouco de tensão.

- Dessa forma, pode ter uma área bege, mas para que tenha tensão deve ter uma área de outra cor.

- Mas contrasta com o quê?

- Bom, o bege pode contrastar...

- N Não, não pode. Me fale com o que contrasta aqui.

- É que não é tão fácil, cara!

- Se concentre aqui, no que você está vendo, contrasta com o quê?

- Há pontos de luz! Pontos de luz específicos que contrastam com esse bege genérico e causam, isso é verdade... desarmonia! Sim, desarmonia! Podemos dizer assim, alguma desarmonia.

\section{- Alguma desarmonia?}

- Sim, me pareceu assim... não muito bom. Alguma desarmonia. Pontos de luz que são como faíscas, faíscas de cor, como paf, paf, paf... e isso desconcentra. Porque alguém tenta encontrar um continuum. 
- Uma dominância!

- Um dominante... sim.

- Mas se pode falar em dominância?

- Bom, você diz dominância. Eu digo dominante.

- Mas dominante é a pessoa.

- Não, dominante também é o tom. $\mathrm{O}$ tom dominante.

- Você pode dizer dominância aromática, por exemplo, pode dizer isso.

$$
\begin{array}{ll}
\text { - } & \text { Sim, claro. } \\
\text { - } \quad \text { E daí? } \\
\text { - } \quad \text { Em relação ao bege. }
\end{array}
$$

A ideia do dispositivo foi imposta paralelamente à tomada de consciência dessas formas de poder, apoiadas por um sistema de regras que uma vez ativadas desenvolvem uma operação autônoma, abrangendo elementos heterogêneos. Os cenários são apresentados como resultados desses dispositivos, cujos mecanismos, quando se tratam de dispositivos críticos, tornam-se visíveis a fim de possibilitar tomar distanciamento deles. Como reflexo desses mecanismos, esses dispositivos artísticos, que produzem um cenário a seu redor, tendem a ser apresentados como máquinas, em muitos casos, abstratas, ou seja, um conjunto de regras que esperam apenas ser ativadas pelo público. Não há quem se responsabilize por elas ou que ofereça a cara ao público. Como se fosse uma tradução cênica do funcionamento de muitas grandes empresas, o público se vê diretamente confrontado com um mecanismo que não oferece outra possibilidade senão aceitar ou não o jogo, e em muitos casos essa última opção já é parte do jogo.

Esse trabalho de Los Torreznos, como resultado da importância conceitual da proposta, também pode ser entendido como um dispositivo. La caverna, de acordo com o mito grego, é o mecanismo clássico, a definição de produção de representações. Ao se fazer visível o jogo, são os espectadores que, transformados em formas mais ou menos difusas da perspectiva de quem está dentro da caverna cênica, precisamente os intérpretes, tornam-se atores sem deixar de ser público. Essas ideias capitais da filosofia platônica são agora essa outra grande abstração, que é o público. 
Se fizermos o exercício de pensar essa obra como um trabalho proveniente de uma área artística relacionada mais com as artes visuais que cênicas, possivelmente se teria materializado uma instalação em alguma sala escura que o público deveria aceitar como parte do percurso através de uma galeria ou um museu. Nesse espaço, estaria o dispositivo, que poderia consistir em um grande espelho ou um mecanismo de gravação que devolveria ao público sua própria imagem/som mais ou menos distorcida. Los Torreznos incorporam o dispositivo. O mecanismo adquire uma forma humana. Eles são a instalação. Também se poderia pensar, considerando a série de Experimentos Torreznos, iniciada alguns anos mais tarde e baseada em intervenções em suas próprias produções, em uma versão experimental de La caverna, em que o público entraria e sairia livremente durante o tempo de duração da obra como se fosse uma instalação dentro de um museu. A pergunta é: qual é a diferença entre um dispositivo material e um dispositivo mantido por algumas pessoas, sejam atores, performers, artistas, ou de qualquer outra identidade? Evidentemente, a resposta depende do modo como os intérpretes mantêm o jogo. Em todo caso, o público já não é confrontado consigo mesmo diante de um mecanismo cujo único rosto é o seu próprio, mas é confrontado com pessoas que estão do outro lado. O sistema de poder que é a representação volta a ter face, olhos, rosto e voz, embora esses atores se apresentam agora tão capturados pelo dispositivo como o público. Pela conversação que eles mantêm, cujo tom claramente improvisado o desenvolve em uma constante corda bamba, eles mesmos não sabem de fato onde estão, o que pode acontecer e onde chegarão. Essa é a ficção a qual a obra se entrega. Embora existam alguns procedimentos e frases que o servem de apoio, a vontade de se lançar de corpo nesse espaço do não-saber entre eles e o público é o que torna crível uma ficção que expressa um desejo, não de controle, em vez disso, de experimentação, de fragilidade e de exposição do efeito de dependência que todo dispositivo tem, não somente deles mesmos, mas também do público. Os atores decidem partilhar o lugar do público a partir desse ato de insegurança. Mediante o que eles chamam, de forma bastante vaga e também cômica, de "fluxo emocional" ou "pacote pré-emocional", são apontadas diferentes maneiras de se situar diante do mecanismo da cena, e deixar de ser um sujeito produzido por ela. E para isso se apela ao público, não individualmente, mas 
como grupo de pessoas que são nesse momento e que, apenas pelo fato de estarem aí, tem a possibilidade de virar o jogo.

- Bege é uma massa compacta que é a soma de tudo o que está aqui. E que fervilha.

- Mas é agradável?

- Cara, mas é claro que é agradável. Como não seria? Há gratidão, eu diria. Emana gratidão.

- Do bege?

- Sim, do bege. É como uma massa da qual saem lampejos de gratidão.

- Mas você os vê?

- Sim. Estou vendo. Olhe, momentos de gratidão especial. Que, bem, eles não duram, se extinguem. São como faíscas. Depois tudo começa de novo.

- Mas vamos observar, por um momento.

- Cara, se você me perguntar, eu respondo.

- Estou surpreso que a gratidão seja manifestada por uma cor. Não entendo. Como é que a cor pode manifestar gratidão?

- Bem, eu não sei. Você me pergunta e eu falo.

- Mas tente aprimorar um pouco.

- Aprimorar? Então eu não estou aprimorando. Há coisas aqui, coisas...

- Agradáveis?

- Bom, sim. Mas há mais do que coisas agradáveis. Há...

- Faíscas?

- Sim, também há faíscas. Há mais do que faíscas. Há, há... emoções em jogo.

- Em jogo?

- $\quad$ Sim, você não percebeu? Então eu vou te dizer. Aqui há importantes emoções em jogo.

- Mas onde? 
- Aqui, circulando. Na maneira de falar.

- Na maneira de falar?

- Sim, há emoções. Sim, é um fluxo emocional que está acontecendo aqui. E que está passando por você. Você não está percebendo? Você está aí como se essa coisa estivesse passando por você. Percebe como passa por você?

- Percebo algo.

- Sim. Vai acabar te atravessando. Porque há muitas emoções em jogo, muitas.

- Mas quantas?

- Há expectativas. Há...

- Ódio?

- Há... ódio também. Há ódio.

- Amor?

— Hum... amor? Há... amor também. Há amor. E acima de tudo, há...

- Medo?

- Medo? Mas o que está acontecendo com você?

- Não... a emoção.

- $\quad$ Porque medo aqui agora, pouco, pouco, muito pouco...

- Deveria ter mais medo. O que há é vontade, vontade.

- $\quad$ Vontade de quê?

- Vontade, em geral. Há vontade.

- Mas você acha que vontade é uma emoção? A vontade não é uma emoção.

- $\quad$ A vontade é...

- Você fala por falar.

- A vontade não é uma emoção. E o que é a vontade?

- A vontade... a vontade... é um pacote de emoções. Vontade de rir, de pular, de...

- Eu vejo isso como algo mais pré-emocional. 
- Pré-emocional?

- É como um pacote pré-emocional. As emoções ainda não foram colocadas em jogo.

- Um pacote pré-emocional? Mas onde estamos chegando, por favor! Vamos falar sobre essa situação como um pacote pré-emocional! Isso é impossível de compreender. "Toma, trago-Ihe aqui um pacote pré-emocional."

"Desapareçamos", título do seguinte capítulo do livro, pode ser entendido como uma estratégia para um movimento político, mas também como uma máxima para os novos atores na busca de procedimentos que não sejam neutralizadas pelo contexto em que operam, o que também pode explicar os autores do livro terem se apresentado como anônimos. Os atores perderam credibilidade ao se transformarem em produto das circunstâncias que os rodeiam. Daí vem a luta da arte, como a da política ou de qualquer outra esfera social, para escapar dos espaços convencionais que delimitam suas possibilidades. Os resultados já estão previstos antes do início da obra. Nada deverá ser muito diferente do que se espera. Se o poder é logístico, deve-se operar nesse mesmo nível, intervindo nos elementos básicos que sustentam essa lógica, entre os quais está o público. Não é possível pensar uma ação senão a partir de uma relação de atrito com o meio em que se desenvolve. Isso levou a uma gama de termos, tais como localização, contexto, espaço específico (site-specific), bem como as operações relativas aos modos de fazer, tais como estratégia, tática, procedimento, que adquiriram uma importância crescente até receber o reconhecimento oficial de agentes culturais e instituições de arte. Esse espaço expandido de criação tornou-se uma espécie de novo credo antiartístico realizado por essas instituições/estruturas que tentam fugir desse tipo de prática que em geral poderiam ser descritas como contextuais. A obra tem que se encarregar do contexto no qual é produzida, mas é muitas vezes o contexto, carregado com o peso das instituições, que acaba se encarregando dela.

Diante do tecido de experiências, distanciamentos e aproximações que alimentam a potência de ação em nível coletivo, a sociedade se mostra como uma estrutura discursiva que justifica determinada necessidade de governo. Qualquer ideia sobre essa abstração que é a sociedade, cujo produto final é o 
público, acaba impondo a aceitação de algumas regras como condição para que um determinado sistema possa funcionar, regras que devem ser aceitas sob a ameaça do caos, do colapso do mercado, da ruína, como preconiza a epígrafe do livro: "Merry Christmas and happy new fear." A aceitação de uma forma de governo, mesmo sem concordar com ela, está associada ao medo social, o medo dos outros, que finalmente somos nós mesmos, e do que essas regras nos defenderiam. Poderíamos questionar se não é também um reflexo desse medo a obediência do público às convenções culturais, resultado do medo de sair do sistema - ou o antissistema cultural, de acordo com o lugar onde nos situamos -, o medo que a obra deixe de funcionar, que não cumpra o papel adequado na cerimônia (contra)cultural.

A opção do Comité Invisible não passa tanto pela desobediência explícita, mas pela insistência em um nível prévio, que consiste em não estar em um espaço enquanto ativista, artista, gerente ou qualquer outra função facilmente identificável, nem como representante de um determinado grupo, partido ou associação, mas simplesmente estar, como mais um, sugerindo um nível de socialização anterior a qualquer identificação. Não se trata de, com isso, deixar de lado os papéis, ou em outras palavras, deixar de ser artista ou ativista, mas assumir essa outra identidade difusa, comum e indeterminada, a partir da qual se propõem outras formas de reconstrução do grupo. A maneira de se organizar coletivamente não responderia, portanto, a interesses prévios, mas a problemas imanentes, decorrentes da necessidade de estar nesse espaço em um determinado momento. Não se trata de se organizar, mas de auto-organizar. $\mathrm{O}$ espaço comum deve nascer da atenção a um presente que sempre vai ter algo de improvisado, incerto e plural.

\footnotetext{
- O que você está vendo é uma paisagem?

- N Não, não é. São roupas.

- Mas são roupas que estão colocadas...

- Estão vestidas em pessoas! Em pessoas!

- Bom, bom... o que temos.

- Isso está cheio de gente!

- Bom, bom.
} 
- Eu queria dar um pouco de mistério...

- Nós terminamos. Agora eu entendo alguns pigarros, e não te via mexer a boca, e soava como um ruído gutural... e eu queria saber como conseguia fazer.

- Talvez eu seja ventríloquo.

- $\quad$ Ah, está bem, as pessoas têm suas habilidades. Mas o que elas estão fazendo? O que as pessoas estão fazendo?

- Olhe, as pessoas estão aí, com a cabeça... Em geral, todos inclinam a cabeça para um lado ou para o outro. Estão assim. Cada um tem uma posição.

- Ui, ui, ui... mas você fala assim... (Deixa pendente a cabeça como se estivesse dormindo).

- Bem, às vezes a cabeça vai mais um pouco... mas em geral estão em sua posição.

- Ou seja, estão como... esperando.

- Sim, pode ser. Eu não sei.

- Mas você conhece a sua posição exata? Como você acha que elas chegaram aí?

- É algo próprio. Que brota deles mesmos.

- Ah, você está me falando sobre sua postura natural, que são pessoas que estão aí tranquilamente. E são muitas?

- Sim, são muitas. Bastante.

Depois dos primeiros 30 minutos, as luzes se apagam e os artistas trocam suas posições. Eles também parecem variar as frases. Aquele que tem a vez de responder se coloca em um nível mais concreto e começa a se referir mais explicitamente ao que está na sua frente e à situação em que estão situados. No entanto, não se trata de identificar individualmente algum espectador, mas de transformar o público em um grupo real de pessoas sensíveis. Os objetos ou qualidades listadas, mesmo que pertençam a alguém, poderiam ser de qualquer um. Algo comparável ao que acontecia em Las posiciones, em que os nomes dos espectadores eram projetados em uma tela, não para identificá-los, mas para insistir que essa enteléquia, que é o público, é com- 
posta de pessoas parecidas, por fazerem parte desse grupo nesse momento, mas também diferentes.

O público está aí. Se alguém se movimenta ou faz algum barulho, não só interfere na conversação dos performers - pelo que deve haver certo cuidado para não chamar muita atenção - mas é o centro da obra. Não se trata somente se os intérpretes, da mesma forma que se iniciou a conversação, se sentem bem, mas como as demais pessoas com quem compartilham essa situação se sentem. Uma perspectiva tátil, mais que visual, transtorna as leis do jogo de representação. Remover as distâncias pré-estabelecidas, devido a uma série de convenções, implica entrar em um terreno movediço, a partir do qual se questiona a rigidez dessas delimitações do espaço sensível ao mesmo tempo em que se recorre ao substrato humano que Ihes dá vida. Em toda a conversação, o tom de dúvida, de equívoco e inclusive, em muitos momentos, de derrota, por não saber como se deve continuar, é efeito do carácter abertamente improvisado de toda a ação. Realizar esse trabalho seguindo o modelo de montagem de texto dramático não faria sentido, embora, talvez por essa mesma razão, não deixaria de oferecer resultados interessantes ao enfatizar o caráter artificial e falso de certo modo inerente a tudo que é cênico, e ao que se faz referência mais de uma vez ao longo da conversação. No entanto, a improvisação a que se submetem os atores os coloca em uma situação de desconhecimento, comparável, de alguma maneira, à do público. $O$ ator renuncia à segurança que o palco poderia dar e tenta se sentir confortável mesmo dentro dessa insegurança, convidando indiretamente os participantes a uma atitude semelhante. É como se lhes dissessem: "não sabemos o que pode acontecer, estamos no mesmo barco". Isso é tudo, não solicitam nenhuma outra forma de participação senão a de que continuem sendo eles mesmos, ou seja, sendo público. Alguns, atores; outros, público; é uma situação forçada, mas pode ser habitada e assim se transformar em outra coisa, uma experiência de algo imprevisível. A horizontalidade entre elementos heterogêneos, mas intercambiáveis pela simetria que guardam, como ator-público, artista-não artista, sujeito-objeto, oferece uma maneira de repensar o jogo de distâncias em que consiste todo dispositivo e toda forma de poder. 
- Não sei, cara, também não se trata agora... Enfim, há pessoas muito interessantes.

- Como estão?

- Em geral, atentas.

- Com uma atenção boa?

- Bom, uma atenção... como se estivessem buscando conhecimento.

- O conhecimento... isso sim é uma grande palavra.

- Elas estão em busca de conhecimento.

- Aqui?

- Bom, elas vão fazer isso em outros lugares também, mas agora estão aqui. Estão com uma atenção desse tipo, tentando sacar alguma coisa... onde não vão encontrar.

- Mas sacar alguma coisa... o quê?

- Não, isso eu já não tenho como saber.

- Por que você não pergunta?

- Não, não. O que acontece é isso.

- Estar em busca de conhecimento, sendo que não há praticamente nada aqui.

- Bom, mas isso acontece aqui e vai acontecer em mais lugares. Não é exclusivo daqui.

- Talvez estejam esperando chegar a algum lugar.

- De uma viagem, você diz?

- Não, não. Como se estivessem esperando que tudo isso faça algum sentido.

- N Não, não acho que pretendem encontrar algum sentido aqui.

Enquanto abstração para justificar uma forma de governo, a sociedade está localizada, segundo a análise do Comité Invisible, em um lugar comparável àquele no qual Platão situou suas ideias, algo fora do alcance, de onde chegam somente as sombras, um argumento para justificar uma ação: "Até o dia de hoje, um dos erros dos revolucionários foi combater no terreno de 
uma ficção que lhes era essencialmente hostil, apropriando-se de uma causa por trás da qual era o próprio governo que avançava disfarçadamente." (p. 187, tradução nossa). A nuestros amigos resta, como diz o título, repensar a possibilidade de agir com os outros, o que é também a potência da cena, em termos reais, no campo do sensível, ou seja, como esse tecido de afetos, inteligências e memórias aponta para a ideia de comunidade enquanto uma outra face da sociedade.

A oposição sociedade-comunidade, fora-dentro, seria transformada em público-atores. No entanto, como defende o Comité Invisible, não há nenhuma sociedade, nenhuma realidade exterior para além do mundo, ou dos mundos nos quais estamos em cada momento. Talvez essa seja a razão pela qual Los Torreznos decidem recorrer também ao mito clássico, a busca de converter essa ideia abstrata, que é o público, em um espaço sensível que de uma forma ou de outra deve se fazer habitável. Nisso consiste a improvisação, em fazer habitável o que ainda não é conhecido, o espaço formado pelos outros, pelo público. Para esses últimos, a tarefa não é muito diferente, eles também precisam se posicionar como parte do evento. Eles vão acabar sendo realmente amigos?

A empreitada está fadada ao fracasso, que é o destino histórico das revoluções e da arte. Os leitores de $A$ nuestros amigos não se tornaram amigos de Julien Coupet, nem os espectadores de La caverna serão menos desconhecidos para Rafael Lamata e Jaime Vallaure do que eram antes. No entanto, ainda que as obras não alcancem seus objetivos, podem se realizar enquanto obras ou movimentos como processos vivos em relação a algumas pessoas que, à medida que também o tenham sentido, deixaram de ser apenas público ou cidadãos para se transformarem, durante o tempo em que a experiência dura, seja assistindo a uma performance, participando de um protesto ou lendo um livro, em indivíduos vivos, ligados a um grupo que partilha uma mesma experiência, capazes por isso não só de serem espectadores ou leitores, mas de provocar e serem provocados, de se sentirem vivos, de fazerem e não saberem como, nem mesmo por que, mas simplesmente fazer porque assistiram a esse trabalho, estiveram nessa manifestação ou leram esse livro. São as paixões alegres, como disse Espinoza, que incitam a ação, ou conforme diz o Comité Invisible: "Nos- 
sa força de choque é feita da mesma intensidade daquilo que vivemos, da alegria que é destilada, das formas de expressão que são inventadas, da capacidade coletiva de suportar a prova daquilo de que é testemunha." (p. 210, tradução nossa).

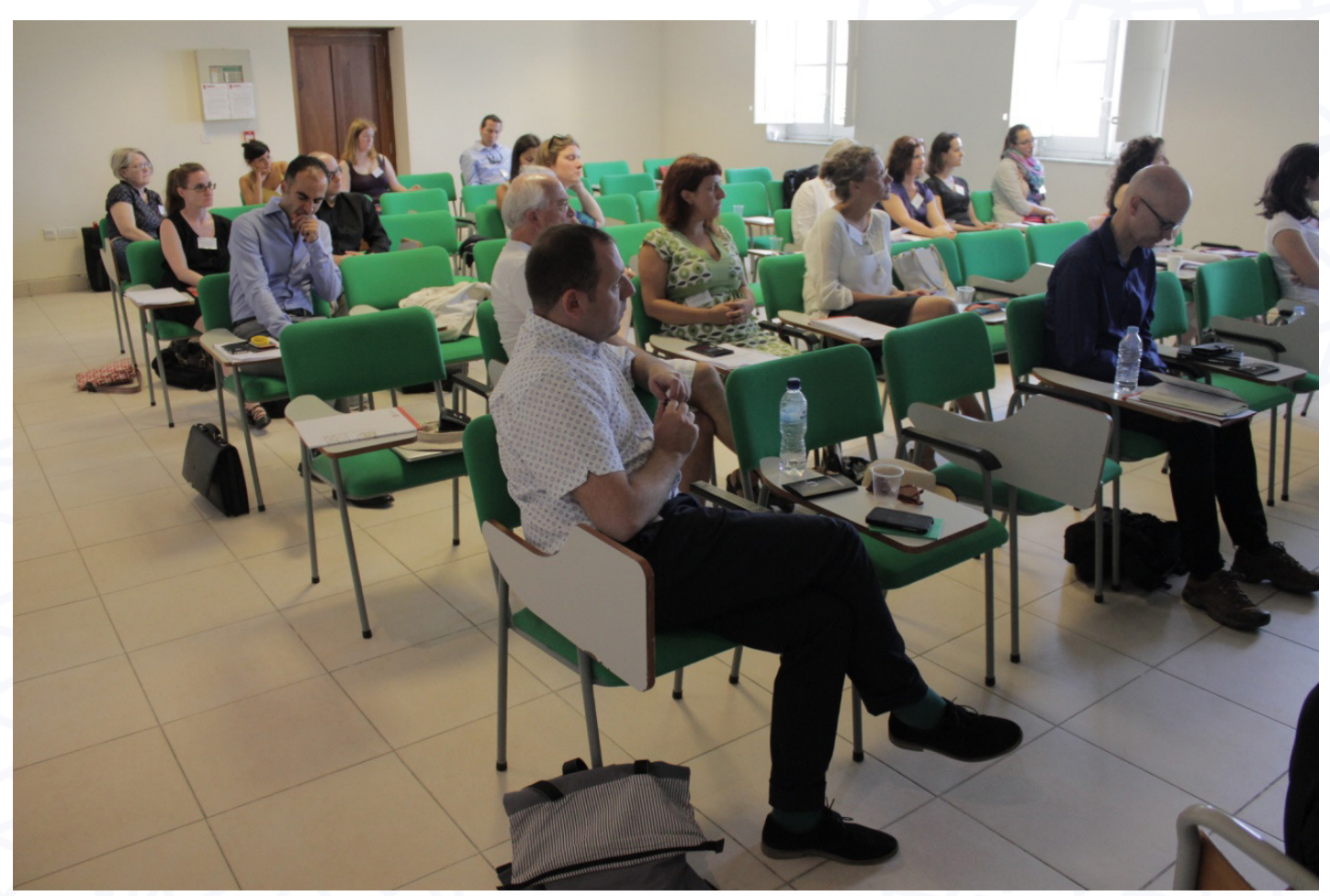

Foto: Francisco Blanes

- Mas você olha muito mais para este lado do que para cima. É como se tivesse algo por aí que...

- Bom, é que existem pessoas atraentes.

- Pessoas atraentes?

- Mais atraentes que você.

- Cara, já imaginava... mas pessoas atraentes em busca de conhecimento. Você me deixa perplexo. Me fale sobre essas pessoas, por favor.

- Não é fácil.

- Mas como elas são?

- Elas têm feições. Têm o rosto normal com narizes, olhos, boca. Há cores. As cores são atraentes. Para mim, as pessoas com cores vivas 
chamam mais atenção. Eu posso vê-las melhor. Agora estou vendo um sapato vermelho.

- E isso é atraente para você?

- Cara, um sapato vermelho... ou melhor.... uma bota vermelha. Isso é legal.

_ $\quad$ Você acha legal uma bota vermelha?

- Sim. Eu acho uma bota vermelha muito legal.

- $\quad E$ isso é a coisa mais interessante que você está vendo, mas, por favor, falávamos sobre pessoas atraentes em busca de conhecimento. $\mathrm{E}$ você só repara em uma bota vermelha!

- São sinais.

- Sinais? Bom, me dê outro sinal.

- É que não podemos entrar no óbvio. O óbvio, já sabemos... é invisível. Enfim, também há uma gravata borboleta, mas é óbvio que uma gravata borboleta também é legal.

- Uma gravata borboleta? Você acha legal uma gravata borboleta? Uma bota vermelha e uma gravata borboleta. É uma loja.

- O quê?

- Essa situação.

- N Não. Você diz isso porque as coisas estão em ordem.

- É que se há uma bota vermelha e uma gravata borboleta, posso imaginar perfeitamente uma terceira coisa. Uma meia. Pode ter perfeitamente uma meia... bege.

- Olha, por exemplo, não se vê armas.

- Cara, ainda bem que não tem armas. Estaríamos ferrados!

- Não tem armas. Não tem escudos.

- São pessoas liberais, portanto, de mente aberta, com vontade...

- Sim, mas não todos.

_ $\quad$ Você já socializou com alguns?

- Com alguns sim, com outros nem tanto.

- Espera, eu vi uma coisa. 
- O quê?

- Não, eu não posso dizer. Olha, eu vou fazer um sinal, piscando os olhos.

- Ah, eu sei onde quer chegar. Você viu uma pistola?

- Não, não. Não há armas.

- Há pessoas que estão com fome. Há pessoas que querem ir ao banheiro.

- Há pessoas atrativas, em busca de conhecimento e com fome. Isso é uma situação...

- $\quad$... é uma situação instável.

- Mas você sabe que... são instáveis, mas são reais.

A instabilidade é o meio necessário para que os grupos mudem. Por isso, o objetivo da maioria dos atores é introduzir um impulso de desestabilização no público. $O$ desejo de mudar as coisas os define como atores. Contudo, essa mesma instabilidade pode supor um perigo. A elaboração teórica de uma sociedade é feita considerando esses possíveis inimigos. A sociedade é uma questão de machos buscando se impor a outros machos. Contudo, negar a existência do inimigo, como da sociedade, do teatro, da vaidade ou de egos, é a essa altura outra forma de teatralidade. Recentemente, Fernández-Savater (2015) recuperou uma imagem proposta por Jean-François Lyotard, na década de 1970, para se opor à mentira das construções políticas, identificadas com a teatralidade no pior sentido do termo, diante da energia empregada pela superfície do corpo social por meio dessa onda de protestos. A profundidade da caixa teatral diante da superfície da qual irrompem as intensidades. Em relação aos amigos, as distâncias são uma forma de jogo, prazer e troca; perante os inimigos, são uma forma de segurança. As distâncias são o elemento fundamental que permite que as representações sejam reconhecidas como o carro-chefe na luta pelos direitos civis. A solução não está em anular as distâncias, as representações ou o teatro.

Esse jogo de oposições, verdadeiro-falso, ação-representação, comunidade-sociedade, é inevitável, como são os inimigos e até mesmo a 
vaidade. O problema é como nos posicionamos diante dele. O olhar do teatro para o movimento de ocupação das praças, que desenvolvemos ao longo deste artigo, fornece à cena outras formas de se relacionar com o público e, portanto, com o mundo, modelos que foram absorvidos pelo campo da arte de uma forma mais evidente a partir do início dos anos 2000. No entanto, o olhar inverso, das praças para o teatro, talvez menos percorrido, também fornece uma leitura sobre a natureza teatral desses movimentos e das próprias práticas colaborativas que não passaram despercebidas pela análise do Comité Invisible. A tomada de consciência da natureza teatral desses movimentos não significa descreditar o seu valor, mas, ao contrário, enfatizar sua potência genuína, que tem a ver precisamente com sua condição teatral; teatral não no sentido de se fazer uma representação, o que muitas vezes parece restrito nesse ambiente, mas no sentido do modo como se elabora essa representação. As comunidades teatrais são aquelas que, pelas formas e atitudes que promovem, desenvolvem maior consciência do fato mesmo de que estão promovendo. A ação de todos juntos promoverem algo como afirmação de um fato coletivo é precisamente a definição de comunidade que dá o Comité Invisible. Isso também é outra maneira de entender o teatral, não em função do efeito externo, mas na intensidade que é gerada internamente. Não se trata de um gesto político em si, mas humano, que se torna político na relação com o contexto social em que opera.

É necessário redefinir o teatral para continuar pensando o social. Embora o artigo de Fernández-Savater apresentasse como mote uma pichação desses movimentos, "it's not about politics, it's about life", é impossível, no plano da história, que as representações e a discussão de ideias estejam fora de um certo teatro. O teatro é também uma espécie de ação coletiva por natureza. Desse lugar, é possível recuperar outro tipo de relação com a representação e a política e talvez também com os inimigos e a vaidade, não por meio de sua negação, mas ao admiti-los confrontando com o que acontece no aqui e agora. Em outras palavras, o problema não é o teatro, nem a política em si ou até mesmo a vaidade, mas a maneira como se pratica. O crime é não fazer teatro, mas fazê-lo errado. Não se trata de abandonar a sociedade, o teatro ou a política, mas pensá-los de outra forma. E 
para isso, pode-se aprender muito com o teatro, basta procurar imagens desses movimentos em defesa de outras formas de sociedade e política. São cenas em sua forma mais pura!

- Vamos ver. Espere um pouco, é que eu estou confuso. É que eu não sei o que você está fazendo com a boca.

- Eu não estou fazendo nada.

- É que não consigo parar de ouvir coisas. Coisas com a boca...

- Ah, estalos. São sons. O ambiente está cheio de sons. Os seres humanos produzem sons quase que constantemente.

- Para seu desgosto.

- Escute.

- Sim, é verdade. Então, deveríamos nos calar. Uau!

- Você gostou?

- Parece que estão encarcerados.

- Há uma articulação.

- Isso mesmo, parece que tudo é o que é, mas na verdade é uma articulação.

- Porque estão vivas. Portanto, em qualquer grupo a que se juntam...

- Você não está fazendo nada?

- N Não, eu não estou fazendo nada. São elas sozinhas.

- Então, possivelmente estão se organizando entre elas mesmas. Elas estão chegando a um estado simbiótico.

- É como um corpo que estivesse sendo carregado.

- É como se estivessem se libertando.

- Mas tem pessoas que já foram embora daqui, percebo que já estão em outro lugar.

- Sim.

- $\quad$ Faça algo. Eu não sei... Diga-Ihes que estamos bem. Que temos emoções.

- Me pergunte se você quiser. 
- Você acha que elas resistirão muito mais?

- Não.

- E como vamos dizer isso?

- Bom, espere. São pessoas que resistem. Além disso, acredito que com essa ideia de conhecimento, elas vêm aqui para resistir. À espera de conhecimento.

- Então elas estão no lugar certo.

- Resistindo?

- Claro que sim.

- De bom tom. Atraentes.

- Bom, então, o que fazemos?

- $\quad$ Eu não sei. Você tem mais perguntas?

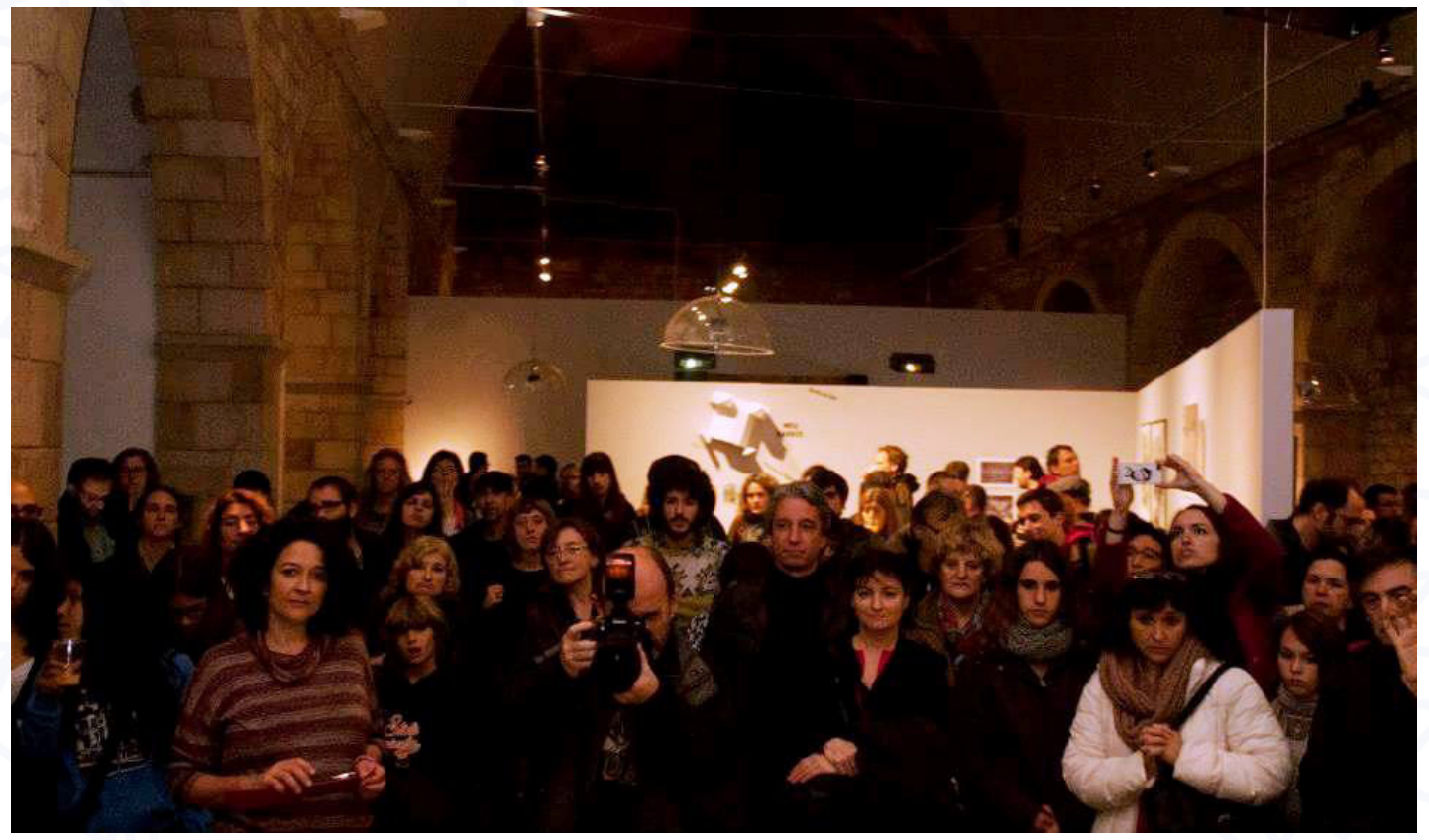

Foto: Francisco Blanes 


\section{Referências bibliográficas}

COMITÉ INVISIBLE. A nuestros amigos. Trad. Vincent E. Barbarroja, León Barrera e Ricardo I. Fiori. Logroño, Espanha: Pepitas de Calabaza e Surplus, 2015.

FERNÁNDEZ-SAVATER, A. La piel y el teatro. Salir de la política. El diario.es, 16 out. 2015. Disponível em: <http: www.eldiario.es/interferencias/piel-teatro-salir-politica_6_442065819.html>. Acesso em: 23 abr. 2016.

Recebido em 10/05/2016

Aprovado em 10/05/2016

Publicado em 30/06/2016 